\title{
Childhood Cerebral Cysticercosis: Clinical Features and Computed Tomographic Findings in 89 Mexican Children
}

\author{
ARTURO LÓPEZ-HERNÁNDEZ and CARMEN GARAIZAR
}

SUMMARY: Cerebral cysticercosis was studied in 89 Mexican children. These patients were divided into two groups; those with proven diagnosis and those in whom the diagnosis was strongly suspected. The frequency of childhood cysticercosis at autopsy is significantly less than reported in adults from the same environment. Symptoms of initial cerebral invasion by the parasite include headache, fever, vomiting, and seizures. Cerebral edema is observed more frequently in children than in adults, and is the most common cause of intracranial hypertension. The cerebral edema generally is associated with an encephalitic syndrome, either a single bout or a chronic course with multiple relapses. Ar-

RÉSUMÉ: Nous avons étudié la cysticercose cérébrale chez 89 enfants mexicains, divisés en deux groupes, un premier dont le diagnostic est certain et un second au diagnostic probable. La fréquence de cysticercose infantile à l'autopsie est significativement inférieure à celle notée chez les adultes du même environnement mais il n'existe pas de différence qualitative dans les présentations cliniques aux 2 âges. Les symptômes initiaux d'envahisement par le parasite sont la céphalée, la fièvre, les vomissements et les crises comitiales. L'oedème cérébral, plus fréquent chez les enfants, était la cause la plus commune de l'hypertension intracrânienne. Le plus fréquemment l'aspect clinique groupe l'oedème terial hypertension, not previously described, was found in two probable cases. The variability of clinical symptomatology thus is great. Symptoms in childhood cerebral cysticercosis may be totally absent, moderate, or severe and ultimately fatal. Computed tomography of the brain is the most useful diagnostic aid, and determines the dynamic neuroradiologic sequence of this disease, since different images appear at each stage to permit its diagnosis. Uncalcified cysticerci may be demonstrated by contrast enhancement if associated with focal cerebral edema; images thus may disappear and reappear in the clinical course of the disease.

cérébral à un syndrome encéphalitique à manifestation simple ou répétitive. Nous avons trouvé une hypertension artérielle chez deux malades, ce qui était préalablement inconnu. Cependant la variabilité de la présentation clinique est importante. La cysticercose cérébrale infantile peut être totalement asymptômatique, modérée ou sévère et ultimement fatale. La tomodensotométrie cérébrale est le test le plus important car il permet des images différentes à chaque étape qui soulignent le diagnostic. Parfois les tests de contrastes permettent, s'il y a oedème cérébral focal, d'identifier les cysticerci non calcifiés. Il est donc possible de voir certaines images apparan̂tre et disparaître au cours de l'évolution clinique.
From the Neurology Service, National Institute of Pediatrics D.I.F., Mexico D.F., Mexico.

Translated from Spanish by Harvey B. Sarnat, Faculty of Medicine, University of Calgary.

Requests for Reprints to: Dr. A. López H., Servicio de Neurologia, Instituto Nacional de Pediatria D.I.F., Insurgentes Sur 3700-C, Mexico, D.F., Mexico 14410 .
In the abundant literature regarding the clinical picture of cerebral cysticercosis, only two reports exist that focus specifically on cerebral cysticercosis in children (De la Torre et al., 1954; López-Hernández and Cedillo, 1976). The largest published mixed series in Mexico only includes eight children of a total of 186 cases (Macias Sánchez and Ordonez, 1970) and the largest series published outside Mexico contains only nine children of 450 cases (Dixon and Lipscomb, 1961). It is obvious that cerebral cysticercosis has received less attention in the child than in the adult, and that because of the small number of published cases at this time, the clinical picture has not been well defined. Nevertheless, since the introduction of computed tomography in Mexico in 1976, many cases have been diagnosed that formerly would have gone undetected, so that this technique has greatly broadened our knowledge of the clinical picture in this disease. The purpose of this paper is to present the clinical, radiologic, and laboratory characteristics of 89 cases of cerebral cysticercosis in patients less than 18 years of age.

\section{MATERIAL AND METHODS}

All cases of cerebral cysticercosis admitted to the National Institute of Pediatrics D.I.F. during the period from 1 November 1970 to 30 November 1980 were reviewed retrospectively. The patients were divided in two groups, according to the precision with which the diagnosis was determined:

Group 1 (proven cysticercosis) was composed of 29 symptomatic and asymptomatic patients in whom cerebral cysticercosis was proved by surgical excisional biopsy or autopsy. 
Group 2 (probable cysticercosis) was composed of 60 symptomatic and asymptomatic patients in whom the plain roentgenograms of the skull showed calcifications suggestive of cysticercosis; micronodular calcifications of $5.12 \mathrm{~mm}$ in diameter with a radiolucent center (Cárdenas and Cárdenas, 1962; Dorfsman, 1963; Santin and Vargas, 1966) or computed tomographic images suggestive of cysticercosis, such as radiolucent cysts, or solid annular nodular cysts (Bentson et al., 1977; Rodriguez-Carbajal et al., 1977; Rodriquez et al., 1978; Lamas et al., 1978).

\section{RESULTS AND COMMENTS}

Tables I to VIII summarize the results of both groups of patients.

Frequency. The frequency of cysticercosis of Mexico has been estimated on the basis of a seroepidemiologic study carried out in a representative sample of the general population, which demonstrated that almost $1 \%$ of the population had positive serologic reactions (Flisser, 1980), but this study does not address the childhood population. With respect to the frequency of cysticercosis estimated in postmortem studies during the 10 year period in which the study was carried out, 18 cases of a total of 3,000 autopsies were found, giving a percentage of $0.60 \%$. Another pediatric series reported a frequency of $0.14 \%$ in 2,900 autopsies (Salas, 1971). These figures are significantly less than those reported in series of adults that vary from $3.6 \%$ (maximum) to $1.03 \%$ (minimum) in several general hospitals in Mexico City (Costero, 1946;
Martinez et al.1 1975). These figures suggest that the frequency of childhood cerebral cysticercosis is less than that of the adult, and the reports of other authors substantiate this view. In Chile, Schenone et al. (1973) found 2 cases among 27,338 unselected autopsies of children, an incidence of $0.007 \%$, and 89 cases among 104,854 autopsies in adults, a yield of $2.39 \%$. In Costa Rica, Piza et al. (1967) found no cases among 4,700 autopsies of children under 7 years of age, while in adults the incidence was $0.5 \%$.

Age and Sex. As indicated in Table I, the majority of cases, $90.9 \%$ are grouped between 6 and 18 years of age. Only 8 cases $(9.1 \%)$ occurred in children 5 years of age or less.

The youngest child in our series is 11 months, and the youngest reported in the literature is 5 days (López, 1943).

TABLE I:

Distribution of Age and Sex

\begin{tabular}{r|ccc|ccc|c}
\hline $\begin{array}{c}\text { AGE } \\
\text { (years) }\end{array}$ & Group 1 & $\begin{array}{c}\text { FEMALE } \\
\text { Group 2 }\end{array}$ & Total & Group 1 & $\begin{array}{c}\text { MALE } \\
\text { Group 2 }\end{array}$ & Total & Total \\
\hline $0-5$ & 2 & 2 & 4 & 4 & 0 & 4 & $8(9.1 \%)$ \\
$5-10$ & 9 & 12 & 21 & 3 & 9 & 12 & $33(37.0 \%)$ \\
$10-15$ & 6 & 18 & 24 & 2 & 7 & 9 & $33(37.0 \%)$ \\
$15-18$ & 1 & 4 & 5 & 2 & 8 & 10 & $15(16.9 \%)$ \\
\hline & 18 & 36 & $54(60.6 \%)$ & 11 & 24 & $35(39.4 \%)$ & $89(100 \%)$ \\
\hline
\end{tabular}

TABLE II:

\section{SYMPTOMS}

\section{Symptomatic}

Intracranial hypertension

Seizures

Alteration of stretch reflexes

Visual impairment

Alterations of cranial nerves

Impairment of consciousness

Impaired coordination

Psychotic reactions

Meningeal signs

Somatic paralysis

Mental deterioration

Asymptomatic

Clinical Manifestations of Cerebral Cysticercosis
GROUP 1

Number

of Cases

16

16

12

$13 \quad 81$

$9 \quad 56$

$10 \quad 62$

$9 \quad 56$

$8 \quad 50$

$6 \quad 37$

$6 \quad 37$

$3 \quad 18$

$3 \quad 18$

13
Number

of Cases

58

25

48

13

11

8

1

9

3

2

6

9

2

\section{Percent}

43

82

22

18

13

1.7

15.5

5.1

3.4

10.2

15.5

\section{TOTAL}

$\begin{array}{cc}\begin{array}{c}\text { Number } \\ \text { of Cases }\end{array} & \text { Percent } \\ 74 & 83.2 \\ 41 & 55 \\ 60 & 81\end{array}$

$\begin{array}{rl}26 & 35 \\ 20 & 27 \\ 18 & 24 \\ 10 & 13 \\ 17 & 22 \\ 9 & 12 \\ 8 & 10.8 \\ 9 & 12 \\ 12 & 16 \\ 15 & 16.8\end{array}$


Although a $60 \%$ predominance of females was found in our series, this difference does not appear to be significant since other authors have found a male predominance (Macias Sánchez and Ordoñez, 1970) or have not found significant differences between the sexes (Escobar, 1952; Briseño et al., 1961).

Clinical Picture. There were significant differences in the clinical manifestations for the two groups of patients (Table II). The first difference is the predominance of asymptomatic patients in Group 1, $44.8 \%$, compared with $3.3 \%$ in Group 2 . This difference is explained by the fact that the cases in Group 1 were discovered at autopsy while those in Group 2 were identified as an incidental finding on a radiograph of the skull or face taken to investigate non-neurologic symptoms. The second difference was the predominance of increased intracranial pressure in symptomatic patients $100 \%$ of the cases in Group 1 contrasted with $43 \%$ in Group 2 . When the chi-square test was applied, this difference was statistically significant $(p<0.05)$. The second most frequent symptom, epilepsy, was present in $82 \%$ of Group 2 cases compared with $75 \%$ of Group 1, but this difference was not statistically significant $(p>0.05)$. These figures suggest that the most frequent clinical manifestation of childhood cysticercosis in proven cases is intracranial hypertension, a feature previously demonstrated in adults (Briseño et al., 1961; Zenteno et al., 1961; Lombardo and Mateos, 1961). The method of selection influences the result; when the non-proven cases are analyzed, intracranial hypertension is not as frequent. Nevertheless, a basic difference exists between the mechanisms for intracranial hypertension in children and adults. In adults, the majority of cases are accompanied by hydrocephalus. Macias Sánchez and Odoñez (1970) determined the size of the ventricles in 75 cases. They found hydrocephalus in 56 and normal sized ventricles in 14 of these cases. Zenteno et al. (1961) reported a series of 30 adult patients, 29 with hydrocephalus and 1 with normal ventricles. Lombardo and Mateos (1961) reported 22 adult cases, 18 of whom presented with dilated ventricles. The mechanism by which hydrocephalus is produced in cysticercosis is fundamentally mechanical due to inflammation and obstruction at the basal cisterns and/or within the ventricular system (Rabiela et al., 1979). In our series, the frequency of hydrocephalus was significantly lower, since of a total of 41 cases of intracranial hypertension, only 13 had ventricular dilatation and 27 exhibited normal or collapsed ventricles. This finding suggests that cerebral edema is more frequent than hydrocephalus as a cause of increased intracranial pressure. The predominance of cerebral edema in infancy also has been observed by Stepien (1962). We propose the term 'cysticercus encephalitis' to denote the clinical picture of cerebral edema, intracranial hypertension, and multiple encephalitic symptoms, as seen during the course of some of these patients. Arterial hypertension was found in two cases, probably related to increased intracranial pressure.
Neither in the literature reviewed nor in our autopsy series were childhood cases of spinal cysticercosis found, despite the frequency of this entity in adults (Cabieses et al., 1959; Testa, 1965; Hesketh, 1965; Trelles et al., 1970; Carmalt et al., 1975; Queiroz, 1975; Garza-Mercado, 1976; Natarajan et al., 1976; Roy et al, 1976; K urrein and Vickers, 1977; Firemark, 1978; Akiguchi et al., 1979). Finally it is noteworthy that we have found a common association of cysticercosis with other entities, such as brain tumors, lupus erythematosis, leukemia, salmonellosis, etc., in the autopsied cases. The clinician should be careful to not dismiss cerebral cysticercosis as a diagnosis simply because symptoms and signs of another entity are present.

Types of Seizures. The variety of seizure most frequently encountered was the generalized tonic-clonic type, with no significant difference between the two groups (Table III).

Clinical Evolution. Table IV demonstrates that as in adults, the clinical course of cysticercosis is quite variable in childhood. It can follow a totally asymptomatic course or acquire a progressive and serious character leading to a fatal outcome (17.2\% mortality in Group 1, 0\% mortality in Group 2). There is also an intermediate form, the most frequent of all, represented by the asymptomatic cases of Group 2 which on occasion follow a chronic course $(36 \%$ with more than 5 years of evolution) and may develop relapses when treatment is discontinued.

Cerebrospinal Fluid (CSF) Findings. As seen in Table $\mathrm{V}$, some cases of

\begin{tabular}{|c|c|c|c|c|}
\hline & $\begin{array}{r}\text { TABL } \\
\text { Types of } \\
\text { GRO }\end{array}$ & & GRC & \\
\hline & Number of Cases & Percent & Number of Cases & Percent \\
\hline Generalized tonic-clonic & 8 & 66.6 & 39 & 80.8 \\
\hline $\begin{array}{l}\text { Partial with elementary } \\
\text { symptomatology }\end{array}$ & 6 & 50.0 & 15 & 31.9 \\
\hline $\begin{array}{l}\text { Partial with complex } \\
\text { symptomatology }\end{array}$ & 1 & 8.3 & 3 & 6.3 \\
\hline Generalized, simple absence & 0 & 0 & 1 & 2.12 \\
\hline More than one type of seizure & 3 & 25.0 & 10 & 21.2 \\
\hline TOTAL & 12 & & 48 & \\
\hline
\end{tabular}


TABLE IV:

Clinical Evolution

GROUP 1

\begin{tabular}{|c|c|}
\hline $\begin{array}{l}\text { Number } \\
\text { of Cases }\end{array}$ & Percent \\
\hline 13 & $\overline{44.8}$ \\
\hline 16 & 55.2 \\
\hline 5 & 17.2 \\
\hline 6 & 34.0 \\
\hline 3 & 10.3 \\
\hline
\end{tabular}

GROUP 2

\begin{tabular}{|c|c|c|c|}
\hline $\begin{array}{l}\text { Number } \\
\text { of Cases }\end{array}$ & Percent & TOTAL & Percent \\
\hline 2 & 3.3 & 15 & 16.8 \\
\hline 58 & 96.7 & 74 & 83.2 \\
\hline 0 & 0 & 5 & 5.6 \\
\hline 8 & 13 & 14 & 15.7 \\
\hline 21 & 36 & 24 & 26.9 \\
\hline
\end{tabular}

TABLE V:

Cerebrospinal Fluid (CSF) Findings

GROUP 1

\begin{tabular}{r}
$\begin{array}{c}\text { Number } \\
\text { of Cases }\end{array}$ \\
\hline 5 \\
13 \\
9 \\
12 \\
3 \\
4 \\
18
\end{tabular}

GROUP 2

\begin{tabular}{l|r} 
Percent & $\begin{array}{r}\text { Number } \\
\text { of Cases }\end{array}$ \\
\hline 27.7 & 17 \\
72.2 & 10 \\
5 \\
10 \\
4 \\
0 \\
27
\end{tabular}

TOTAL

\begin{tabular}{c|ccc} 
Percent & $\begin{array}{c}\text { Number } \\
\text { of Cases }\end{array}$ & & Percent \\
\cline { 2 - 3 } 37.9 & 22 & & 48.8 \\
23 & & 51.1 \\
& 14 & 31.1 \\
22 & 48.8 \\
7 & 15.5 \\
4 & 8.8
\end{tabular}

TABLE VI

Findings in Roentgenograms of Skull

\begin{tabular}{|c|c|c|c|c|c|c|}
\hline & GR & & GR & & & \\
\hline & $\begin{array}{l}\text { Number } \\
\text { of Cases }\end{array}$ & Percent & $\begin{array}{l}\text { Number } \\
\text { of Cases }\end{array}$ & Percent & $\begin{array}{l}\text { Number } \\
\text { of Cases }\end{array}$ & Percent \\
\hline Normal & 6 & 35.2 & 6 & 10 & 12 & 13.5 \\
\hline Intracranial hypertension & 9 & 52.9 & 13 & 21.6 & 22 & 24.7 \\
\hline Intracranial calcifications & 3 & 17.6 & 44 & 73.3 & 47 & 52.8 \\
\hline
\end{tabular}

cysticercosis did not show any CSF abnormalities. When abnormalities were present, the most frequent was pleocytosis. The presence of eosinophils in the CSF is considered pathognomonic of cysticercosis in Mexico (Hernández-Peniche et al., 1968), but it is noteworthy that only 7 of the $45 \mathrm{CSF}$ specimens in our cases showed eosinophils. In series of confirmed cases in adults, the frequency of CSF abnormalities is higher than in our series, 90.5\% (Lombardo and Mateos, 1961), but if probable and confirmed cases are combined, the frequency is lowered to $53.9 \%$ (Marcas Sánchez and Ordoñez, 1970).
Skull Roentgenograms and Pneumoencephalograms. Tables VI and VII indicate the number of patients in whom intracerebral calcifications were detected in plain roentgenograms of the skull, and the findings in pneumoencephalograms with air introduced either in the lumbar subarachnoid space or directly through the brain into the ventricles.

Computed Tomography of the Brain. As has already been mentioned, cerebral computed tomography has become the most valuable diagnostic aid supporting the clinical diagnosis of cerebral cysticercosis. Nevertheless, the images cannot be considered totally specific because other entities closely resembling cysticercosis may be confused with it in the computed tomographic scan. The lesions found in the 27 patients in whom computed tomography was carried out are summarized in Table VIII and illustrated in Figure 1 to 5 . These radiographic pictures may be categorized as: 1) Cerebral edema and small ventricles, which radiographically resemble pseudotumor cerebri. This finding may appear alone or associated with cysts (Figure 1). It was found in 17 of 28 cases. 2) Cystic lesions that are only observed after contrast enhancement and may be solid or annular in the form 
TABLE VII:

Findings in Pneumoencephalogram and Ventriculogram

Number of Cases

Normal ventricular system

Cerebral edema and small ventricles

Hydrocephalus

Hydrocephalus and intraventricular cysts

Solitary frontal mass lesion

TOTAL
GROUP 1

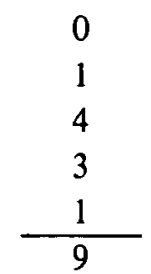

GROUP 2

Number of Cases

\begin{tabular}{l}
3 \\
1 \\
4 \\
0 \\
0 \\
\hline 8
\end{tabular}

TABLE VIII:

Findings in Cerebral Computed Tomography

GROUP 1

GROUP 2

\section{Number \\ of Cases}

Diffuse cerebral edema and collapsed ventricles, without nodular lesions

Hydrocephalus and calcified cyst within 4 th ventricle

Radiolucent cysts associated with micronodules and hydrocephalus

Hydrocephalus and multiple nodular lesions

Single tumor-like cystic lesion

1
1
1
1
1

Images suggestive of cysticercosis cysts that appear single after contrast enhancement

\section{solid}

cystic (annular)

radiolucent cysts

nodular calcifications and/or micronodules with calcification

Cerebral edema and small ventricles

Hydrocephalus, non communicating
Number

of Cases

Percent

47.8

16

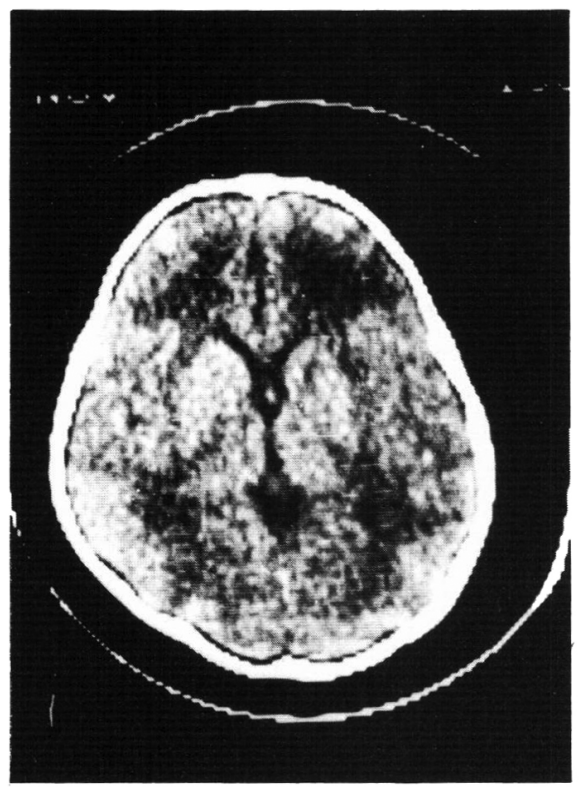

Figure 1-Diffuse cerebral edema and collapsed ventricles in a seven year old child with intracranial hypertension due to cerebral cysticercosis. Onset of clinical symptoms of initial acute stage was two months earlier.

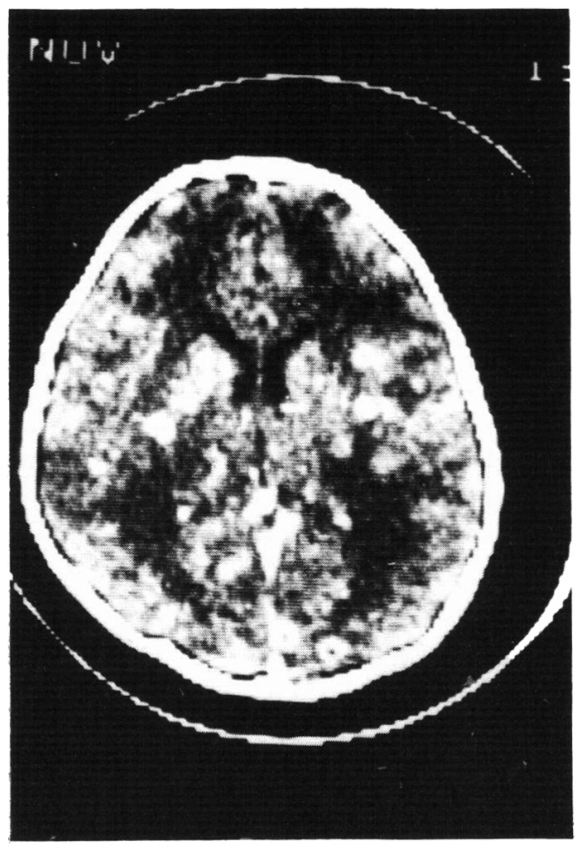

Figure 2-Multiple cystic lesions and annular cysts appear only after the injection of contrast material in the same patient as in Figure 1. of a 'donut' (Figure 2). 3) Radiolucent cysts that probably represent infarcts or cysticerci surrounded by cerebral edema (Figure 3). 4) Calcified cysts and microcysts, visible without enhancement (Figure 4). 5) Hydrocephalus from basal cisternal and/or ventricular obstruction. 6) Solitary tumorlike images (Figure 5).

Eleven of 28 cases in our series, studied with computed tomography several months or years after the onset of symptoms, suggested that both the clinical picture and the images demonstrated by computed tomography represent intermediate or late stages of the natural history of cerebral cysticercosis, as seen in Figures 3 to 5. However, in the remaining 17 cases in which images were detected from the beginning of the course, fever, headache, vomiting and seizures were presenting symptoms. In this early stage, computed tomography invariably showed various degrees of 


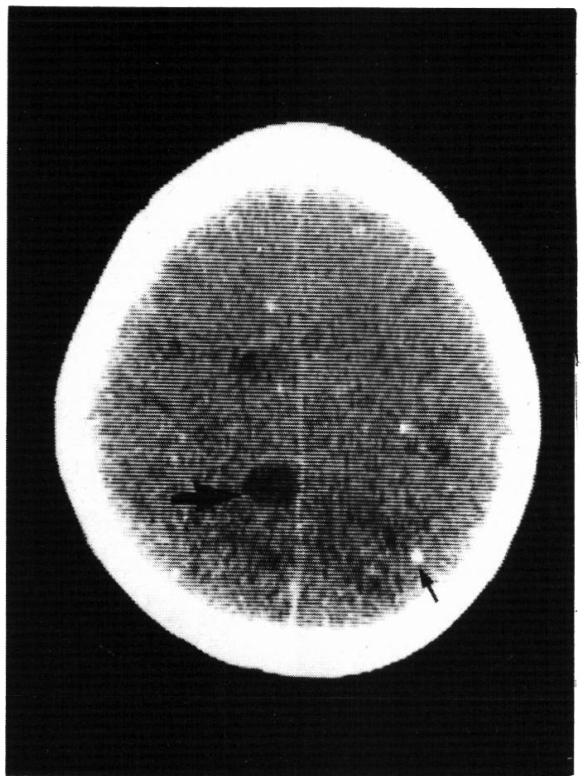

Figure 3 - Arrows indicate radiolucent areas (infarcts) and microcysts seen without contrast enhancement. Onset of symptoms one year earlier. Intermediate stage.

cerebral edema and normal or collapsed ventricles. If edema was severe, the characteristic lesions of cysticercosis were not visualized in the first studies, but only after several weeks or months, after the edema had subsided. Even at this time, the cysticercus lesions appear only after injection of contrast material as in Figures 1 and 2. We propose that as in other infectious diseases, the initial symptoms and cerebral edema could be caused by the arrival and implantation of the cysticercus in the central nervous system (primary infection). It also is probable that symptoms and signs do not occur, or that they are very mild as neurologically asymptomatic cases, in the non-parenchymatous or ventricular forms. The initial phenomenon of edema is later limited to the region of the brain around the cysticercus, permitting the demonstration by contrast enhancement of an image in the form of a ring or round mass, either annular or solid. After the focal edema resolves, the tomographic image (but not the cysticercus) fades or disappears, and only reappears if it calcifies or again becomes surrounded by a zone of cerebral edema. In one of the cases proven at surgery, the image of the cysticercal cysts had 'disappeared' and

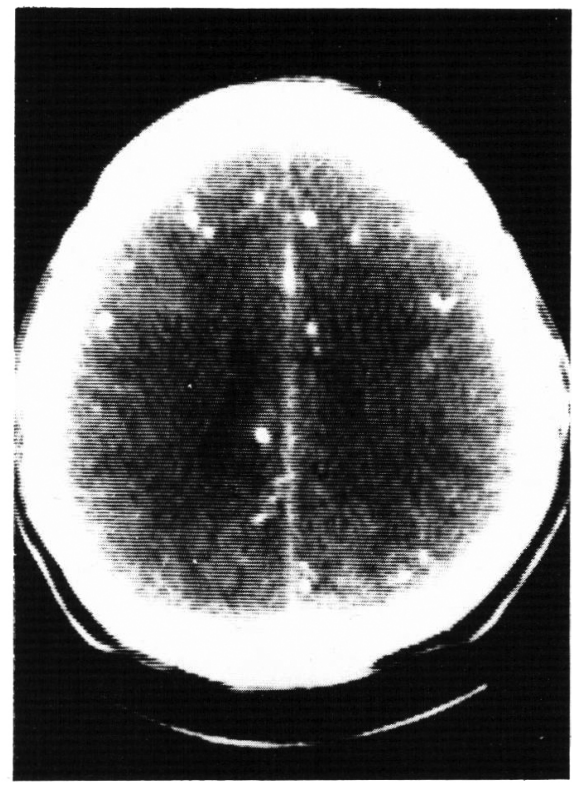

Figure 4-In final stage, multiple calcified cysticerci are visible without contrast enhancement. They also appeared in the plain roentgenograms of the skull. Onset of clinical manifestations was five years earlier.

'reappeared' on two occasions that coincided chronologically with alternating exacerbations and remissions of intracranial hypertension.

Cysticercosis also may present in the form of an isolated tumor mass, as occurred in one of the cases proven at surgery (Figure 5).

Because of these changes, the following tomographic sequence emerges: (a) diffuse cerebral edema; (b) cystic lesions that appear with contrast enhancement; (c) disappearance of the cystic images; (d) calcification. The diagnosis of cerebral cysticercosis by means of computed tomography is only feasible in stages $b$ and $d$. In an environment of high prevalence, the absence of cystic images in the computed tomogram of the brain does not completely rule out cerebral cysticercosis.

\section{ACKNOWLEDGEMENT}

The authors would like to thank Dr. López Corella of the Department of Pathologic Anatomy of the National Institute of Pediatrics, D.I.F., for having made the material from autopsy available to us. We also thank $\mathrm{Dr}$. Harvey B. Sarnat for his translation of the manuscript from Spanish.

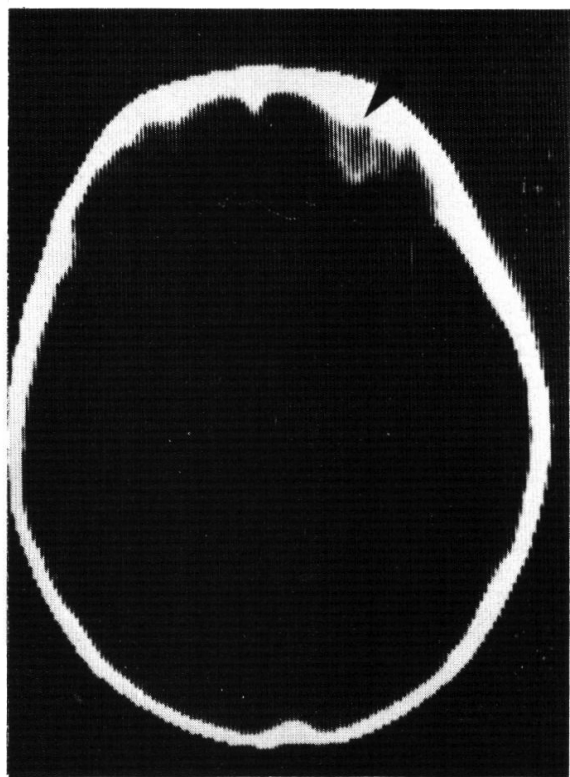

Figure 5 - Solitary tumor-like cyst in the frontal region, resulting from a cysticercus surrounded by granulomatous tissue subsequently demonstrated in the histopathologic examination of the lesion.

\section{REFERENCES}

AKIGUCHI, I., FUJIWARA, T., MATSUYAMA, H., MURANAKA, H., KAMEYAMA, M. (1979). Intramedullary spinal cysticercosis. Neurology (Minneap), 29:1531-1534.

BENTSON, J.R., WILSON, G.H., HELMER, E., WINTER, J. (1977). Computed tomography in intracranial cysticercosis. J. Computed Tomography, 1:464-471.

BRISEÑNO, C.E., BIAGI, F., MARTÍNEZ, B. (1961). Cisticercosis, observaciones sobre 97 casos de autopsia. Prensa Méd. Mex., 26:193-197.

CABIESES, F., VALLENAS, M., LANDA, R. (1959). Cysticercosis of the spinal cord. J. Neurosurg., 16:337-341.

CÁRdenAS, Y., CÁRDENAS, J. (1962). Cysticercosis 1I. Pathologic and radiologic findings. J. Neurosurg., 19:635-640.

CARMALT, J.E., THEIS, J., GOLDSTEIN, E. (1975). Spinal cysticercosis. West. J. Med., 123:311-313.

COSTERO, I. (1946). Tratado de Anatomia Patológica. Ed. Atlante, México, p. 1468.

De la TORRE, J.A., RENTERIA, G., CISNEROS, F. (1954). Cisticercosis cerebral en el niño. Bol. Méd. Hosp. Infantil Méx., 11:643-654.

DIXON, H.B., LIPSCOMB, F.M. (1961). Cisticercosis: an analysis and follow up of 450 cases. Privy Council Medical Res. Special Rep. Ser. (London), 299:1-58. 
DORFSMAN, J. (1963). The radiologic aspects of cerebral cysticercosis. Acta Radiol (Diag), 1:836-842.

ESCOBAR, I.A. (1952). Cisticercosis cerebral con el estudio de 20 casos (se concluye). Arch. Mex. Neurol. Psiquiat., 1:149-167.

FIREMARK, H.M. (1978). Spinal cysticercosis. Arch. Neurol., 35:250-251.

FLISSER, A. (1980). The Immunology of human cysticercosis. In Larralde, C., WilIms, K., Ortiz-Ortiz, L., and Sela, M. (editors). New York: Molecules, Cells and Parasites in Immunology. Academic Press, pp. 131-132.

GARZA-MERCADO, R. (1976). Intramedullary cysticercosis. Surg. Neurol., 5:331-332.

HERNÁNDEZ-PENICHE, J., RODRÍGUEZTRUJILLO, H. (1968). Sindrome encefalitico por cisticercosis. Prensa Mèd. Mex., 23:391-396.

HESKETH, K.T. (1965). Cysticercosis of the dorsal cord. J. Neurol., Neurosurg. Psychiat., 28:445-448.

KURREIN, F., VICKERS, A.A. (1977). Cysticercosis of the spine. Ann. Trop. Med. Parasitol., 71:213-217.

LAMAS, E., ESTEVEZ, J. (1978). Dos casos de cisticercosis cerebral diagnosticados con tomografia axial computarizada. Rev. Clín. Española, 151:53-55.

LOMBARDO, L., MATEOS, J.H. (1961). Cerebral cysticercosis in Mexico. Neurology (Minneapolis), 11:824-828.

LOPEZ, A.W. (1943). Diagnóstico clínico y biológico de la cisticercosis del S.N.C. y de las meninges. Analecta. Med. 4:17-26.

LÓPEZ-HERNÁNDEZ, A., CEDILLO, J. (1976). Cisticercosis intracraneana en los niños. A nálisis de 48 casos. Rev. Mex. Ped., $45: 277.285$.
MACIAS SÁNCHEZ, R., ORDOÑEZ, de M.S. (1970). Cisticercosis cerebral. Diagnóstico clínico, radiológico y de laboratorio, prognóstico. Análisis de 186 casos. Prensa Méd. Mex., 25:6-14.

MÁRQUEZ, M.H., AUSTRIA, B. (1969). Cisticercosis en el Hospital General de México, estudio anátomo-patológico de 155 casos. Rev. Lat. Amer. Patol., 8:79-86.

MARTINEZ, H., ROMERO, H., MARTÍNEZ, R., BOISSELIER, E., MARTíNEZ, E. (1975). Cisticercosis cerebral humana. Cirugia y Cirujanos, 43:507-520.

NATARAJAN, M., RAMASUBRAMANIAN, K.R. MUTHU, A.K. (1976). Intramedullary cysticercosis of spinal cord. Surg. Neurol., 6:157-158.

PIZA, J., FERNÁNDEZ, A., SOTO, M., GARCÍA, A. (1967). Cisticercosis cerebral. Estudio anatomoclinico de 24 casos en Costa Rica. Acta Med. Costarriqueña. 10:517.

QUEIROZ, L.D.S., FILHO, A.P., CALLEGARO, D., LÓPEZ DE FARIA, L. (1975). Intramedullary cysticercosis: Case report, literature review and comment on pathogenesis. J. Neurol. Sci., 26:6 1-70.

RABIELA, M.T., RIVAS, A., RODRIGUEZ, IJ. (1979). Consideraciones anatomopatológicas sobre la cistercosis cerebral como causa de muerte. Patología, 17:119-136.

RODRÍGUEZ-CARBAJAL, J., PALACIOS, E., AZAR-KIA, B., CHURCHILL, R. (1977). Radiology of cysticercosis of the central nervous system including computed tomography. Radiology, 125:127-131.
RODRIGUEZ, J.C., GUTIÉRREZ, R.A., VALDES, O.D., DORFSMAN, J.F. (1978). The role of computed axial tomography in the diagnosis and treatment of brain inflammatory and parasitic lesions; our experience in México. Neuroradiology, 16:458-461.

ROY, R.N., BHATTACHARYA, M.B., CHATTERJEE, B.P. (1976). Spinal cysticercosis. Surg. Neurol., 6:129-131.

SALAS, M. (1971). Procesos patológicos más frecuentes considerados como factores importantes en la causa de muerte en los niños juzgados a través de la revisión de 2900 estudios post-mortem realizados - en el Departamento de Patologia del Hospital Infantil de México. Gac. Méd. Mex., 102:216-225.

SANTÍN, G., VARGAS, J. (1966). Roentgen study of cysticercosis of the nervous system. Radiology, 86:520-528.

SCHENONE, H. RAMÍREZ, R., ROJAS, A. (1973). Aspectos epidemiológicos de la neurocisticercosis en América Latina. Bol. Chileno Parasit. 28:61-72.

STEPIEN, L. (1962). Cerebral cysticercosis in Poland. Clinical symptoms and operative results in 132 cases. J. Neurosurg., 19:505513.

TESTA, C. (1965). Cysticercose intramédullaire isolée opeerée: Présentation d'un cas. Rev. Neurol. (Paris), 113:536-541.

TRELlES, J.O., CACERES, A., PAlMiNo, L. (1970). La cysticercose médullaire. Rev. Neurol. (Paris), 123:187-202.

ZENTENO, G., MARTÍNEZ, B., BIAGI, F. (1961). Observaciones sobre la Cisticercosis humana. Rev. Fac. Medicina (México), 3:617-632. 